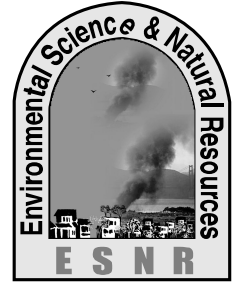

\title{
Growth Regulatory Activities of Different Extracts of Tinospora Cordifolia on Some Vegetable Seeds with their Chemical Investigation
}

\author{
S. Aktar ${ }^{1}$, M. A. Sayed ${ }^{2}$, M. R. Islam ${ }^{3}$, B. Roy ${ }^{4}$ and M. A. Hossain ${ }^{5}$ \\ $1,2,3,5$ Department of Biochemistry and Molecular Biology, ${ }^{4}$ Department of Agricultural Chemistry \\ Hajee Mohammad Danesh Science and Technology University, Dinajpur
}

\begin{abstract}
An experiment was conducted to investigate the growth regulatory activities of different extracts of Tinospora cordifolia on radish (Raphanus sativus), swamp cabbage (Impoea aquatica) and lady's finger (Hibiscus esculentus) with the attempt for chemical investigation of effective plant extract. The chloroform extract of Tinospora cordifolia significantly increased and enhanced germination, growth of shoot length and root length of radish and lady's finger whereas and delayed germination, growth of shoot length and root length of swamp cabbage seeds compared with control. In the same way, ethanol extract of Tinospora cordifolia significantly increased germination, growth of shoot length and root length of swamp cabbage followed by control and chloroform extract. Our study reveals that different extracts of Tinospora cordifolia contain growth regulatory active principle. Among the extracts, chloroform extract was shown better performance in terms of percent germination, growth of shoot and root length of radish and lady's finger. To find out effective compound from chloroform extract, thin layer chromatography was done and showed five distinct compounds. Further study is needed to determine structure for finding growth regulatory compound for agricultural usage.
\end{abstract}

Key words: Chemical investigation, Extract, Growth regulatory activity, Vegetables,

\section{Introduction}

There are different types of plant such as herbal or medicinal, fruit trees, woody, necrotic, herbaceous, shrubs, weeds etc. in plant kingdom. Most of them have effective medicinal values, growth regulatory, herbicidal and pesticidal effects and also toxic values. According to WHO, around $80 \%$ of the world's 5.86 billion inhabitants depend on traditional medicine for their primary health care, majority of which use plant or their active principles (Gias Uddin, 1998). The most important of these bioactive compounds of plant are alkaloids, flavonoids, tannins and phenolic compounds. There are different types of medicinal plants in Bangladesh. We have found that there is worth of 11 million US dollars medicinal plant market in Bangladesh, which have been imported but not in the name of medicinal plants rather in the name of spices and other products (Bregum, 2004). The cultivation of medicinal plants in Bangladesh will lead to the conservation and also protect the biodiversity. One of the medicinal plants Tinospora cordifolia belongs to the Menispermaceae family and is commonly known as Gulancha or Tinospora in English and Giloya in Hindi. The plant is a glabrous climbing shrub found throughout Bangladesh, India, Myanmar and Sri Lanka typically growing in deciduous and dry forests. It is a widely used shrub in folk and ayurvedic systems of medicine. It is reported to possess anti-spasmodic, anti-inflammatory, anti-allergic, anti-oxidant properties (Singh et al., 2003). The root and stem of $T$. cordifolia are prescribed in combination with other drugs as an anti-dote to snake bite and scorpion sting (Zhao et al., 1991). T. cordifolia is widely used in Indian ayurvedic medicine for treating diabetes mellitus (Stanely et al., 2001). It is reported that the daily administration of either alcoholic or aqueous extract of $T$. cordifolia decreases the blood glucose level and increases glucose tolerance in rodents (Grover et al., 2001).

Bangladesh is a developing country and more than $80 \%$ people are directly and indirectly related to agriculture. Diverse crops are cultivated in different areas. Quick growing crops are the best way of achieving return. Regarding these plant extracts play a vital role for increasing crop yield like growth promoter. The availability of medicinal plants demands the isolation, separation, purification and characterization of physiologically active principles which are actually useful in the field of agriculture. To our knowledge, there is scarcity of information on the phytotoxic effects of $T$. cordifolia on succeeding agricultural crops. The attention is being needed to the importance of rotation in medicinal plant or between medicinal herbs and other crops, due to strong allelopathic effects of medicinal plants (Basotra et al., 2005; Guo et al., 2006; Nazir et al., 2007). Various types of extracts of $T$. cordifolia and shial mutra having bioactive compound increase or decrease germination and growth rate of crops (Roy et al. 2004; Roy, S.R. 2006). The observation of the growth regulatory activities of different extracts of $T$. cordifolia have progressed research works in the field of natural product chemistry. Different experiments were conducted to understand the effect of different extracts of $T$. cordifolia on various diseases. But data are not available about the effect of different extracts of $T$. cordifolia on germination, plumule and radicle growth of some selected vegetables crops. Keeping this view in mind the research has been undertaken to investigate the growth regulatory effects of different extract of $T$. 
cordifolia and isolate the different bioactive compounds from the effective extract of $T$. cordifolia.

\section{Materials and Methods}

\section{Experimental Site}

The experiment was conducted at research laboratory, Department of Biochemistry and Molecular Biology, Hajee Mohammad Danesh Science and Technology University, Dinajpur, Bangladesh, during January 2011December 2011.

Collection of $T$. cordifolia and summer vegetable seeds T. cordifolia stems were collected from Chalksudum of Chirirbandar under Dinajpur district. Radish (Raphanus sativus), Swamp cabbage (Impoea aquatic) and Lady's finger (Hibiscus esculentus) seeds were selected due to their short growth period and available in sub-tropical countries. The seeds of these vegetables were collected from the Dinajpur seed market. The purity percentages and germination percentages of these seeds were 95 and 90 , respectively.

\section{Preparation of aqueous extracts of $T$. cordifolia}

About $50 \mathrm{gm}$ of fresh stems of $T$. cordifolia were cut into smaller pieces and blended by blender and taken into a $1000 \mathrm{ml}$ reagent bottle with water up to the mark. It was kept for 72 hours at room temperature with regular interval of stirring. After 72 hours the resulting brownish and dark solution were filtered through three layers of Whatman No. 1 filter paper and was taken into another $1000 \mathrm{ml}$ bottle. The filtrates of plant extract were stored and used for treating the seeds of vegetable crops.

\section{Preparation of chloroform extract and ethanol extract of $T$. cordifolia}

Ten kilogram of green and fresh stem were cleaned and cut into small pieces. The small pieces of stem were dried in sun light for 7 days followed by oven at $70^{\circ} \mathrm{C}$ for 48 hours. The dried stem was grinded by grinding machine and obtained about $4 \mathrm{~kg}$ powder. Two kilogram powder was dissolved in five liter absolute chloroform (96\%) and another two kilogram in absolute ethanol (98\%) and incubated for 72 hours for a suspension. These suspensions were filtered with thin and clean cloth and finally filtered by filter paper. The suspension was dried by BUCHI Rota vapor R-114 connected with BUCHI water bath B- 480 at $70^{\circ} \mathrm{C}$. The dried extract was weighed by digital balance. Five percent solution of each extract was prepared with water for treating the seeds of vegetable crops. The individual plant extracts were investigated as following sequential treatments:
a) Water or control $\left(\mathrm{T}_{\mathrm{c}}\right)$
b) Aqueous extract of $T$. cordifolia $\left(\mathrm{T}_{1}\right)$
c) Chloroform extract of T. cordifolia $\left(\mathrm{T}_{2}\right)$
d) Ethanol extract of $T$. cordifolia $\left(\mathrm{T}_{3}\right)$

\section{Set up for the investigation of vegetable crop seeds}

Thirty six petridish were cleaned and divided into three groups for three vegetables seeds and two sheets filter papers were placed on it. For each vegetable seeds, petridish were divided into four treatments with three replications each petridish separately (Fig 1). $15 \mathrm{ml}$ of each aqueous, chloroform, ethanol extract and distilled water put in each petridish according to experimental design. After that 25 seeds of each vegetable crop were kept in each petridish. The petridishes were placed in natural diffused light under laboratory conditions at $29 \pm 2{ }^{\circ} \mathrm{C}$ temperature and relative humidity of $85 \pm 5 \%$. Five $\mathrm{ml}$ of water was applied per day per petridish to keep constant moisture. The percent germination, shoot length, root length and completion of germination were recorded.

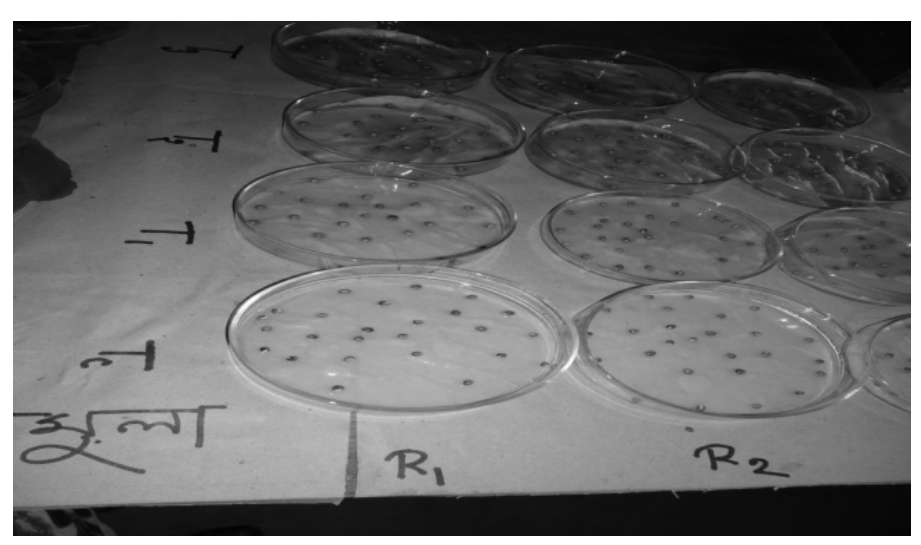

Fig. 1. Seeds set up for the investigation 


\section{Identification of effective extracts}

analyzed statistically using Duncan's Multiple Range Test (DMRT). After analyses these data, it was observed that the chloroform extract of $T$. cordifolia enhance the germination, shoot length and root length of radish and Lady's finger and inhibit germination, shoot length and root length of swamp cabbage compared with control.

\section{Chemical investigation of effective extract of $T$.} cordifolia

Thin Layer Chromatography (TLC) technique was used to detect the presence of compounds in a crude extract in
The

collected

data

were which $\mathbf{R}_{\mathbf{f}}$ value of each component was calculated by using this formula (Furniss et al., 1989):

$$
\mathrm{R}_{\mathrm{f}}=\frac{\text { Distance traveled by the component }}{\text { Distance traveled by the solvent front }}
$$

About five different compounds were detected by Thin Layer Chromatography (TLC) and separated by preparative TLC and calculated to find out five distinct
values
(Fig.
2

$\mathrm{R}_{\mathrm{f}}$

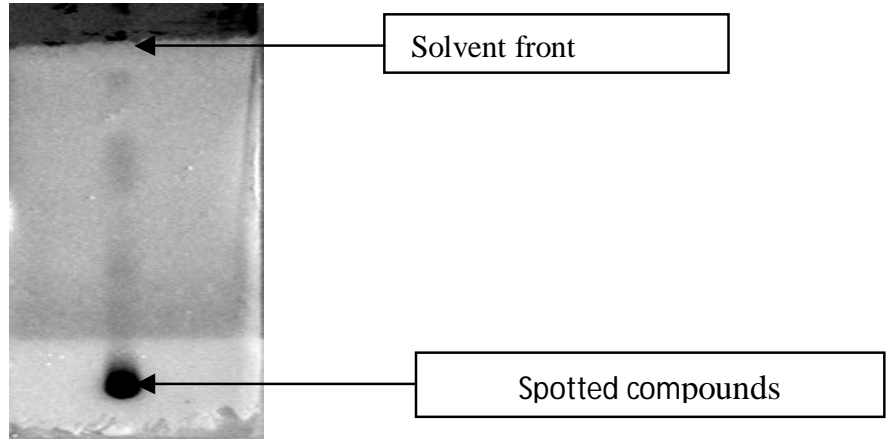

Fig. 2. Thin Layer Chromatographic Plate

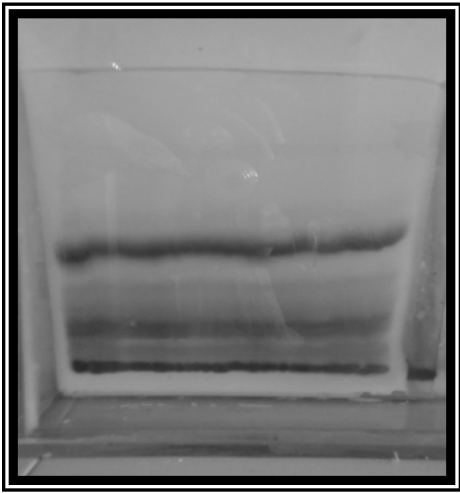

Fig. 3. Preparative TLC

Test for sterols of different purified compound

After purification of different crude compounds, the isolated purified compounds were subjected to test for sterol by Salkowaski reaction and LibermannBurchard reactions.

\section{Results and Discussions}

The results showed that growth regulatory activity in different extracts of $T$. cordifolia. The result of the study has been presented in Tables $(1,2 \& 3)$. 
J. Environ. Sci. \& Natural Resources, 5(1): 133 - 140, 2012

Table 1. Effects of $T$. cordifolia (gulancha) stem extract on percent germination of radish, swamp cabbage and lady's finger seeds

\begin{tabular}{|c|c|c|c|c|c|c|c|c|c|}
\hline \multirow[t]{3}{*}{ Treatments } & \multicolumn{9}{|c|}{$\%$ Germination } \\
\hline & \multicolumn{3}{|c|}{ Radish } & \multicolumn{3}{|c|}{ Swamp Cabbage } & \multicolumn{3}{|c|}{ Lady's finger } \\
\hline & $1^{\text {st }}$ day & $3^{\text {rd }}$ day & $6^{\text {th }}$ day & $1^{\text {st }}$ day & $3^{\text {rd }}$ day & $6^{\text {th }}$ day & $1^{\text {st }}$ day & $3^{\text {rd }}$ day & $6^{\text {th }}$ day \\
\hline Control (water) & $28.00 \mathrm{a}$ & $56.00 \mathrm{a}$ & $84.00 \mathrm{~b}$ & $30.67 \mathrm{a}$ & $56.00 \mathrm{a}$ & $74.67 \mathrm{a}$ & $29.30 \mathrm{a}$ & $41.33 b$ & $61.33 \mathrm{a}$ \\
\hline Aqueous Extrct & $18.67 \mathrm{~b}$ & $34.67 \mathrm{~b}$ & $57.33 \mathrm{c}$ & $12.00 \mathrm{~b}$ & $34.67 \mathrm{~b}$ & $61.33 b$ & $12.00 \mathrm{~b}$ & $29.33 c$ & $44.00 \mathrm{~b}$ \\
\hline Chloroform extract & $29.33 \mathrm{a}$ & $54.67 \mathrm{a}$ & $96.00 \mathrm{a}$ & $16.00 \mathrm{~b}$ & $44.00 \mathrm{ab}$ & $74.67 \mathrm{a}$ & $36.00 \mathrm{a}$ & $50.67 \mathrm{a}$ & $64.00 \mathrm{a}$ \\
\hline Ethanol Extract & $25.33 \mathrm{a}$ & $53.33 \mathrm{a}$ & $82.67 \mathrm{~b}$ & $36.00 \mathrm{a}$ & $52.00 \mathrm{a}$ & $78.67 \mathrm{a}$ & $16.00 \mathrm{~b}$ & $49.33 \mathrm{ab}$ & $58.67 \mathrm{a}$ \\
\hline
\end{tabular}

Data expressed in mean value; different letter in a column differ significantly at $5 \%$ level of significance (as per DMRT) 
Table 2. Effects of T. cordifolia (gulancha) stem extract on shoot length of radish, swamp cabbage and lady's finger seeds

\begin{tabular}{|c|c|c|c|c|c|c|c|c|c|}
\hline \multirow[t]{3}{*}{ Treatments } & \multicolumn{9}{|c|}{ Shoot length $(\mathrm{cm})$} \\
\hline & \multicolumn{3}{|c|}{ Radish } & \multicolumn{3}{|c|}{ Swamp cabbage } & \multicolumn{3}{|c|}{ Lady's finger } \\
\hline & $5^{\text {th }}$ day & $8^{\text {th }}$ day & $11^{\text {th }}$ day & $5^{\text {th }}$ day & $8^{\text {th }}$ day & $11^{\text {th }}$ day & $5^{\text {th }}$ day & $8^{\text {th }}$ day & $11^{\text {th }}$ day \\
\hline Control (water) & $0.9933 \mathrm{~b}$ & $3.163 \mathrm{a}$ & $4.567 \mathrm{ab}$ & $0.9267 \mathrm{~b}$ & $4.067 \mathrm{~b}$ & $5.233 \mathrm{~b}$ & $1.637 \mathrm{a}$ & $3.667 \mathrm{a}$ & $5.380 \mathrm{~b}$ \\
\hline Aqueous Extract & $1.380 \mathrm{~b}$ & $2.250 \mathrm{a}$ & $2.433 \mathrm{~b}$ & $1.580 \mathrm{a}$ & $1.093 \mathrm{c}$ & $1.303 \mathrm{~d}$ & $1.467 \mathrm{~b}$ & $1.750 \mathrm{~b}$ & $0.0000 \mathrm{~d}$ \\
\hline Chloroform extract & $2.373 \mathrm{a}$ & $2.427 \mathrm{a}$ & $5.873 \mathrm{a}$ & $1.573 \mathrm{a}$ & $4.033 \mathrm{~b}$ & $4.900 \mathrm{c}$ & $1.617 \mathrm{a}$ & $3.563 \mathrm{a}$ & $5.737 \mathrm{a}$ \\
\hline Ethanol Extract & $1.220 \mathrm{~b}$ & $2.013 \mathrm{a}$ & $3.787 \mathrm{ab}$ & $1.893 \mathrm{a}$ & $5.233 \mathrm{a}$ & $5.867 \mathrm{a}$ & $1.527 \mathrm{~b}$ & $3.280 \mathrm{a}$ & $5.163 \mathrm{c}$ \\
\hline
\end{tabular}

Data expressed in mean value; different letter in a column differ significantly at $5 \%$ level of significance (as per DMRT)

Table 3. Effects of $T$. cordifolia (gulancha) stem extract on root length of radish, swamp cabbage and lady's finger seeds

\begin{tabular}{|c|c|c|c|c|c|c|c|c|c|}
\hline \multirow[t]{3}{*}{ Treatments } & \multicolumn{9}{|c|}{ Root length $(\mathrm{cm})$} \\
\hline & \multicolumn{3}{|c|}{ Radish } & \multicolumn{3}{|c|}{ Swamp Cabbage } & \multicolumn{3}{|c|}{ Lady's finger } \\
\hline & $5^{\text {th }}$ day & $8^{\text {th }}$ day & $11^{\text {th }}$ day & $5^{\text {th }}$ day & $8^{\text {th }}$ day & $11^{\text {th }}$ day & $5^{\text {th }}$ day & $8^{\text {th }}$ day & $11^{\text {th }}$ day \\
\hline Control (water) & $1.627 \mathrm{ab}$ & $2.827 \mathrm{a}$ & $4.767 \mathrm{a}$ & $1.273 \mathrm{a}$ & 324793 a & $4.380 \mathrm{~b}$ & $1.353 \mathrm{a}$ & $3.017 \mathrm{a}$ & $5.033 \mathrm{~b}$ \\
\hline Aqueous Extract & $1.060 \mathrm{~b}$ & $1.620 \mathrm{a}$ & $1.120 \mathrm{~b}$ & $0.7667 \mathrm{a}$ & $0.8633 \mathrm{~b}$ & $0.9633 \mathrm{c}$ & $1.257 \mathrm{a}$ & $1.330 \mathrm{~b}$ & $0.45 \mathrm{~d}$ \\
\hline $\begin{array}{l}\text { Chloroform } \\
\text { extract }\end{array}$ & $1.727 \mathrm{a}$ & $3.153 \mathrm{a}$ & $6.047 \mathrm{a}$ & $1.247 \mathrm{a}$ & $2.837 \mathrm{a}$ & $4.417 \mathrm{~b}$ & $1.340 \mathrm{a}$ & $3.177 \mathrm{a}$ & $5.300 \mathrm{a}$ \\
\hline Ethanol Extract & $1.180 \mathrm{ab}$ & $1.873 \mathrm{a}$ & $3.500 \mathrm{ab}$ & $1.347 \mathrm{a}$ & $3.057 \mathrm{a}$ & $5.500 \mathrm{a}$ & $1.303 \mathrm{a}$ & $2.617 \mathrm{a}$ & $4.733 \mathrm{c}$ \\
\hline
\end{tabular}

Data expressed in mean value; different letter in a column differ significantly at 5\% level of significance (as per DMRT) 
Effect of T. cordifolia (gulancha) extracts on radish

\section{Percent germination}

The percent germination was counted in $1^{\text {st }}, 3^{\text {rd }}$ and $6^{\text {th }}$ days presented in Table 1 . In the $1^{\text {st }}$ day, the highest germination was found in $\mathrm{T}_{2}(29.33 \%)$ followed by $\mathrm{T}_{\mathrm{c}}$ and $\mathrm{T}_{3}$. The lowest germination was recorded in $\mathrm{T}_{1}(18.67 \%)$. In $3^{\text {rd }}$ day, the highest germination was found in $\mathrm{T}_{\mathrm{c}}(56.00 \%)$ followed by $\mathrm{T}_{2}$ and $\mathrm{T}_{3}$. The lowest germination percentage was recorded in $\mathrm{T}_{1}(34.67 \%)$. In $6^{\text {th }}$ day, the highest germination was found in $\mathrm{T}_{2}(96.00 \%)$ and the lowest germination was recorded in $\mathrm{T}_{1}(57.33 \%)$.

\section{Shoot length}

Shoot length of radish was significantly influenced by different types of stem extracts (Table 2). After 5 days after sowing (DAS), chloroform extract of $T$. cordifolia shows the highest shoot length $(2.373 \mathrm{~cm})$ whereas the lowest shoot length $(0.9933 \mathrm{~cm})$ was recorded in control treatment. The highest shoot length of radish seedling was found in $\mathrm{T}_{2}$ i.e. chloroform extract of $T$. cordifolia $(2.427 \mathrm{~cm})$ at 8 DAS that was statistically similar to others. At 11 DAS the highest shoot length was recorded in $T_{2}$ $(5.873 \mathrm{~cm})$ and the lowest was found in $\mathrm{T}_{1}(2.433$ $\mathrm{cm})$. At 14 DAS, The highest shoot length of radish seedling was found in $\mathrm{T}_{2}$ i.e. chloroform extract of $T$. cordifolia $(6.633 \mathrm{~cm})$ followed by $\mathrm{T}_{\mathrm{c}}$ and $\mathrm{T}_{3}$. On the other hand the lowest shoot length was recorded in $\mathrm{T}_{2}$ $(2.667 \mathrm{~cm})$. Possibly chloroform extract of $T$. cordifolia contain some growth regulatory or other bioactive substance which may responsible for enhancing the shoot length of radish.

\section{Root length}

Root length of radish was significantly influenced by different types of stem extract (Table 3). After 5 DAS, chloroform extract of $T$. cordifolia showed the highest root length $(1.727 \mathrm{~cm})$ which was similar to $\mathrm{T}_{\mathrm{c}}$ and $\mathrm{T}_{3}$ treatments, whereas the lowest root length $(1.06 \mathrm{~cm})$ was recoded in $\mathrm{T}_{1}$ treatment. The highest root length of radish seedling was found in $T_{2}$ i.e. chloroform extract of $T$. cordifolia $(3.153 \mathrm{~cm})$ at 8 DAS that was statistically similar to others. At 11 DAS the highest root length was recorded in $T_{2}$ $(6.047 \mathrm{~cm})$ and the lowest was found in $\mathrm{T}_{1}(1.12 \mathrm{~cm})$. At 14 DAS, The highest root length of radish seedling was found in $\mathrm{T}_{2}$ i.e. chloroform extract of $T$. cordifolia $(6.333 \mathrm{~cm})$ followed by $\mathrm{T}_{\mathrm{c}}$ and $\mathrm{T}_{3}$. On the other hand the lowest shoot length was recorded in $\mathrm{T}_{2}$ $(1.00 \mathrm{~cm})$. Possibly chloroform extract of $T$. cordifolia contain some growth regulatory or other bioactive substance which may responsible for enhancing the root length of radish.
Effect of $T$. cordifolia (gulancha) extract on swamp cabbage

\section{Percent germination}

The percent germination was counted in $1^{\text {st }}, 3^{\text {rd }}$ and $6^{\text {th }}$ days presented in Table 1 . In the $1^{\text {st }}$ day, the highest germination percentage was found in $\mathrm{T}_{3}$ (36.00\%) followed by $\mathrm{T}_{\mathrm{c}}$ treatment. The lowest percent germination was recorded in $\mathrm{T}_{1}(12.00 \%)$. In $3^{\text {rd }}$ day, the highest germination percentage was found in $\mathrm{T}_{\mathrm{c}}(56.00 \%)$ followed by $\mathrm{T}_{2}, \mathrm{~T}_{3}$ and $\mathrm{T}_{1}(34.67 \%)$, respectively. In $6^{\text {th }}$ day, the highest germination percentage was found in $\mathrm{T}_{3}(78.67 \%)$ similar to that of $\mathrm{T}_{\mathrm{c}}$ and $\mathrm{T}_{2}$ treatments, respectively. On the other hand the lowest germination percentage was recorded in $\mathrm{T}_{1}(61.33 \%)$.

\section{Shoot length}

Shoot length of swamp cabbage was significantly influenced by different types of stem extracts (Table 2). After 5 DAS, Ethanol extract of $T$. cordifolia showed the highest shoot length $(1.893 \mathrm{~cm})$ followed by $\mathrm{T}_{1}, \mathrm{~T}_{2}$ and $\mathrm{Tc}(0.9267 \mathrm{~cm})$ treatment, respectively. The highest shoot length of Swamp cabbage seedling was found in $\mathrm{T}_{3}$ i.e. Ethanol extract of $T$. cordifolia $(5.233 \mathrm{~cm})$ and the lowest shoot length was recorded in $\mathrm{T}_{1}(1.093 \mathrm{~cm})$ in the 8 DAS. At 11 DAS the highest shoot length was recorded in $\mathrm{T}_{3}(5.867 \mathrm{~cm})$ and the lowest was found in $\mathrm{T}_{1}(1.303 \mathrm{~cm})$. Possibly ethanol extract of $T$. cordifolia contain some growth regulatory or other bioactive substances which may responsible for enhancing the shoot length of swamp cabbage.

\section{Root length}

Root length of swamp cabbage was significantly influenced by different types of stem extract (Table 3). After 5 DAS, Ethanol extract of Tinospora cordifolia was the highest root length $(1.347 \mathrm{~cm})$ which was statistically similar to all other treatments. The highest root length of Swamp cabbage seedling was found in $\mathrm{T}_{3}$ i.e. ethanol extract of Tinospora cordifolia $(3.057 \mathrm{~cm})$ followed by $\mathrm{T}_{\mathrm{c}}, \mathrm{T}_{2}$ and $\mathrm{T}_{1}$ $(0.8633 \mathrm{~cm})$, respectively at 8 DAS. At 11 DAS the highest root length was recorded in $\mathrm{T}_{3}(5.50 \mathrm{~cm})$ and the lowest was found in $\mathrm{T}_{1}(0.9633 \mathrm{~cm})$. Possibly ethanol extract of $T$. cordifolia contain some growth regulatory or other bioactive substance which may responsible for enhancing the root length of swamp cabbage.

\section{Effect of $T$. cordifolia (gulancha) extract on lady's finger \\ Percent germination}

The highest germination percentage was counted in $1^{\text {st }}, 3^{\text {rd }}$ and $6^{\text {th }}$ days presented in (Table 1 ). In the $1^{\text {st }}$ day, highest germination percentage was found in $\mathrm{T}_{2}$ 
(36.00\%) followed by $\mathrm{T}_{\mathrm{c}}$ treatment. The lowest germination was recorded in $\mathrm{T}_{1}(12.00 \%)$. In $3^{\text {rd }}$ day, the highest germination was found in $\mathrm{T}_{2}(50.67 \%)$ which was followed by $\mathrm{T}_{3}$ treatment. The lowest germination was recorded in $\mathrm{T}_{1}(29.33 \%)$. In $6^{\text {th }}$ day, the highest germination percentage was found in $\mathrm{T}_{2}$ (64.00\%) followed by $\mathrm{T}_{\mathrm{c}}$ and $\mathrm{T}_{3}$, respectively. On the other hand the lowest germination was recorded in $\mathrm{T}_{1}$ $(44.00 \%)$.

\section{Shoot length}

Shoot length of lady's finger was significantly influenced by different types of stem extracts (Table 2). After 5 DAS, chloroform extract of Tinospora cordifolia showed the highest shoot length $(1.617 \mathrm{~cm})$ which was similar to $\mathrm{T}_{\mathrm{c}}$ treatment. The lowest shoot length $(1.467 \mathrm{~cm})$ was recoded in $\mathrm{T}_{1}$ treatment. The highest shoot length of lady's finger seedling was found in $\mathrm{T}_{2}$ i.e. chloroform extract of $T$. cordifolia $(3.563 \mathrm{~cm})$ followed by $\mathrm{T}_{\mathrm{c}}, \mathrm{T}_{3}$ and $\mathrm{T}_{1}(1.75 \mathrm{~cm})$, respectively at $8 \mathrm{DAS}$. At $11 \mathrm{DAS}$ the highest shoot length was recorded in $\mathrm{T}_{2}(5.737 \mathrm{~cm})$ and no shoot was found in $\mathrm{T}_{1}(00 \mathrm{~cm})$. Possibly chloroform extract of $T$. cordifolia may contain some growth regulatory or other bioactive substances which may responsible for enhancing the shoot length of lady's finger.

\section{Root length}

Root length of lady's finger was significantly influenced by different types of stem extracts (Table
3). After 5 DAS, chloroform extract of $T$. cordifolia showed the highest root length $(1.34 \mathrm{~cm})$ which was similar to all other treatments. At 8 DAS, the highest root length of ladys finger was found in $\mathrm{T}_{2}$ i.e. chloroform extract of $T$. cordifolia $(3.177 \mathrm{~cm})$ that was statistically similar to $\mathrm{T}_{\mathrm{c}}$ and $\mathrm{T}_{3}$ treatments. On the other hand the lowest root length was found in $T_{1}$ $(1.33 \mathrm{~cm})$. At 11 DAS the highest root length was recorded in $\mathrm{T}_{2}(5.30 \mathrm{~cm})$ and the lowest was found in $\mathrm{T}_{1}(0.45 \mathrm{~cm})$, respectively. Possibly chloroform extract of $T$. cordifolia may contain some growth regulatory or other bioactive substances which may responsible for enhancing the root length of lady's finger.

\section{Chemical investigation of chloroform extract of $T$. cordifolia}

The results in this experiment indicate that the chloroform extract of $T$. cordifolia have increasing or inhibitory activity on germination, shoot and root length of early growth vegetables. To find out this active compound Thin Layer Chromatography (TLC) of chloroform extract of $T$. cordifolia was done and showed five distinct compounds at Hexane: Ethylacetate $(5: 1 \mathrm{v} / \mathrm{v})$. This result suggested that it contained five distinct compounds, designated as $F_{1}$, $F_{2}, F_{3}, F_{4}$ and $F_{5}$ respectively (Table 4). These compounds were detected in iodine tank and the $R_{f}$ value were calculated by using the formula (Furniss $e t$ al., 1989).

Table 4. $\mathrm{R}_{\mathrm{f}}$ values of detected components of Tinospora cordifolia

\begin{tabular}{|l|l|l|l|}
\hline Name of the Plant Species & Ratio(Hexane:Ethylacetate) & Detected component & $\mathrm{R}_{\mathrm{f}}$ value \\
\hline \multirow{4}{*}{ Tinospora cordifolia } & \multirow{3}{*}{$5: 1$} & $\mathrm{~F}_{1}$ & 0.94 \\
\cline { 3 - 4 } & & $\mathrm{F}_{2}$ & 0.81 \\
\cline { 3 - 4 } & & $\mathrm{F}_{3}$ & 0.72 \\
\cline { 3 - 4 } & & $\mathrm{F}_{4}$ & 0.45 \\
\cline { 3 - 4 } & & $\mathrm{F}_{5}$ & 0.18 \\
\hline
\end{tabular}

\section{Chemical test for sterol for isolated fraction}

The results of the different chemical test were presented in Table 5 . The fractions $\mathrm{F}_{3}, \mathrm{~F}_{4}$ and $\mathrm{F}_{5}$ were showed both the Salkowaski and Libermann Burchard reaction positive which indicated that $F_{3}, F_{4}$ and $F_{5}$ may be steroid type compounds.

Table 5. Chemical tests for sterol for isolated fractions

\begin{tabular}{|l|c|c|}
\hline Name of fraction & Salkowaski reaction & Liebermann-Burchard reaction \\
\hline Fraction 1 & -ve & -ve \\
\hline Fraction 2 & -ve & -ve \\
\hline Fraction 3 & $+\mathrm{ve}$ & $+\mathrm{ve}$ \\
\hline Fraction 4 & +ve & $+\mathrm{ve}$ \\
\hline Fraction 5 & +ve & $+\mathrm{ve}$ \\
\end{tabular}




\section{Conclusions}

Finally, we can say chloroform extract of $T$. cordifolia enhance the germination percentage, shoot and root length of radish and lady's finger in all respects comparison with other treatments. Therefore, it can be said that chloroform extracts of T. cordifolia may contain growth regulatory or other bio-active substances. Further investigation including separation of individual fractions and structure determination of active compounds are essential to make conclusive remarks.

\section{Acknowledgements}

We are very grateful to the Department of Biochemistry and Molecular Biology, Hajee Mohammad Danesh Science and Technology University (HSTU), Dinajpur.

\section{References}

Basotra, R; Chauhan, S. and Todaria, N.P. 2005. Allelopathic effects of medicinal plants on food crops in Garhwal, Himalaya. Journal of Sustainable Agriculture, 26:43-56.

Bregum, F. 2004. The present status of medicinal plants in Bangladesh Article 94, Volume 3, Supplement, $2: 34-34$.

Furniss, S.B; Hannafold, J. A; Smith, G.P. and Tatchell, R.A. 1989. Vogel's Text Book of Practical Organic Chemistry, $5^{\text {th }}$ Edition.

Grover, J.K; Vats, V; Rathi, S.S. and Dawar, R. 2001. Traditional Indian anti-diabetic plants attenuate progression of renal damage in streptozotocin induced diabetic mice, Journal of Ethnopharmacol, 76:233-238.
Guo, L.P; Huang, L.Q. and Jiang, Y.X. 2006. Soil deterioration during cultivation of medicinal plant and ways to prevent it. China Journal of Chinese Materia, 31:714-717.

Nazir, T.A; Uniyal, K. and Todaria, N.P. 2007. Allelopathic behaviour of three medicinal plant species on traditional agriculture crops of Garhwal Himalaya, India. Agroforestry Systems, 67:183-187.

Roy, S.R. 2006. Biological activity of leaves of some ornamental plants with emphasis on chemical investigation. MS Thesis, Department of Agricultural Chemistry and Biochemistry, Hajee Mohammad Danesh Science and Technology University, Dinajpur.

Roy, B; Uddin, M.N; Islam, M.J; Amin, R; Islam A.T.M.S. and Halder B. C. 2004. Leaf Extracts of Shiyalmutra (Biumea laera De) as botanical inseticides against lesser grain borer and rice weevil. Journal of Biological Science, 40:1-2.

Singh, J; Sinha, K; Sharma, A; Mishra, N.P. and Khanuja S.P. 2003. Traditional uses of Tinospora cordifolia (Guduchi). Journal of Medicinal Aromatic Plant Science, 25:748-51.

Stanely, M; Prince, P. and Menon, V.P. 2001. Antioxidant action of Tinospora cordifolia root extract in alloxan diabetic rats. Phytother Research, 15:213-218.

Uddin, G.M. 1998. Standardization of herbal preparation, The Independent, Monday, 30 march, $13 \mathrm{p}$.

Zhao, T.F; Wang, X; Rimando, A.M. and Che, C. 1991. Folkloric medicinal plants: Tinospora sagittata var. cravaniana and Mahonia bealei. Planta Medicine, 57:505. 